(C). С. Подпрятов ${ }^{1,2,4}$, С. Є. Подпрятов ${ }^{1,2,3}$, С. Г. Гичка ${ }^{2}$, В. Г. Гетьман ${ }^{4}$, А. В. Макаров ${ }^{4}$, Г. С. Маринський ${ }^{3}$ О. Ф. Петренко ${ }^{5}$ О. В. Чернець ${ }^{3}$, В. А. Ткаченко ${ }^{3}$, Д. В. Тарнавський Київський міський центр електрозварювальної хірургії та новітніх хірургічних технологій ${ }^{1}$ Київська міська клінічна лікарня № $1^{2}$ Інститут електрозварювання імені Є. О. Патона НАН України ${ }^{3}$ Національна медична академія післядипломної освіти імені П. Л. Шупика ${ }^{4}$ Національний університет біоресурсів і природокористування України ${ }^{5}$

\title{
ОСОБЛИВОСТІ ВІДНОВЛЕННЯ ТКАНИННИХ СТРУКТУР У ПЕРІОД ДО 90 ДІБ У МІЖКИШКОВИХ АНАСТОМОЗАХ, СТВОРЕНИХ ІЗ ЗАСТОСУВАННЯМ ТЕХНОЛОГІЇ ЕЛЕКТРОЗВАРЮВАННЯ ЖИВИХ ТКАНИН
}

\begin{abstract}
Резюме. Наявність гнійно-некротичного запалення під швами в міжкишковому анастомозі визначає загоєння грубим рубцем, що заміщує тканинну структуру, на тлі інкапсуляції та відторгнення шовного матеріалу.

Мета дослідження - вивчити особливості відновлення тканинних структур у ділянці міжкишкового анастомозу, створеного із застосуванням технології електрозварювання живих тканин у період репарації і фрормування рубця.

Матеріали і методи. Досліджували зміни в міжкишковому анастомозі через 4; 7; 21; 45 та 90 діб після його створення 3 погляду відновлення структури тканин та стінки кишки. Циркулярний електрозварний тонко-тонкокишковий анастомоз наклали 18 свиням у хронічному експерименті. Використовували електрозварювальні апарати ЕК-300М1 і Патонмед ЕКВ3-300 та прототипи циркулярних електрозварювальних інструментів. Базове забарвлення препаратів анастомозу здійснювали за гематоксиліном та еозином або за Ван-Гізон.

Результати досліджень та їх обговорення. Через 7 діб міцність електрозварного анастомозу на розрив перевищила 220 мм рт. ст. З'явилися ознаки відновлення тканинних структур: симетричне зближення меж візуально незмінених ділянок кишки, порівняно з 4-ю добою, на тлі орієнтації та фрормування жмутків різноспрямованих колагенових волокон. Сформовано молоду сполучну тканину з сіткою артеріол. Через 21 добу ознак запалення не було. Волокниста сполучна тканина мереживно охоплює тканинні структури і проникає на 5 мм вглибину симетрично з'єднаних країв кишки. Функціонують судини різного типу. Через 45 діб наявна колагенізація уздовж усіх мембран і оболонок. Судини з'єднаних ділянок забарвлюються крізь лінію анастомозу. Через 90 діб тенденції до злиття у суцільний рубець немає, складки слизової відновлені, а лінія з'єднання ледь виразна за зміною орієнтації волокон.

Висновки. Каркасна безперервність оболонок кишечника, що відновлюється на місці створення електрозварного анастомозу, є передумовою багатого наскрізного кровопостачання та симетричного відновлення тканинної структури стінки кишки вже через 7 діб. Відсутність сторонніх тіл і мікроорганізмів у структурі електрозварного анастомозу зумовлює зникнення запалення через 21 добу, що також є складовою формування мережевної ніжної, а не заміщувальної структури з'єднання сполучної тканини в ньому.
\end{abstract}

Ключові слова: електрозварювання; тканина; анастомоз; кишка; відновлення; структура; судини; рубець; загоєння.

ВСтУП Наявність гнійно-некротичного запалення в стінці кишки у клінічно неускладненому традиційному шовному міжкишковому анастомозі (МА), поширеного некрозу слизової оболонки визначають тривалість періоду деструкції колагену і призводять до вторинного діастазу країв МА. Загоєння в цих умовах відбувається вторинним натягом шляхом виповнення дефекту грубим рубцем [1-3]. Введення фрібринового клею не поліпшує загоєння, а тільки дещо знижує частоту ускладнень МА [4]. Величина рубця є похідною від величини діастазу, яка, у свою чергу, є похідною від поширеності некротично-деструктивних змін.

Також вираження рубцювання залежить від типу перебігу запалення, зумовленого діяльністю мікрофрлори, що міститься у просвіті кишечника й активізується в ділянці деструктивно-некротичних змін [5, 6].

Ще одним чинником, який підтримує запалення і дефрормуюче рубцювання у зоні традиційного МА, є процес інкапсуляції та відторгнення шовного матеріалу, за допомогою якого МА був створений. Процес відмежування стороннього матеріалу, його інкапсуляції та/або відторгнення є тривалим, супроводжується заміщенням грубоволокнистою сполучною тканиною структур стінки кишки, через які шовні елементи були проведені, та через які мігрує у просвіт кишки.

Поєднання вказаних особливостей загоєння шовного МА спричиняє десрормуючі зміни в структурі стінки кишки, які змінюють проходження хвилі перистальтики і кишкового вмісту [7], та порушують ії̈ пропульсивну фрункцію навіть в неускладнених спостереженнях $[8,9]$, але й у разі подовженого та посиленого фріброзування можуть стійко звужувати просвіт кишки вже через 60 діб після створення MA $[5,10]$.

Встановлені клінічні властивості антибактерійної стійкості електрозварного МА (ЕМА) [11], продуктивний характер загоєння, без ознак деструкції [12, 13], спричиняють інтерес до дослідження його тканинної структури, включно у віддаленому періоді фрормування рубця.

Метою дослідження було вивчити особливості відновлення тканинних структур у ділянці міжкишкового анастомозу, створеного із застосуванням технології електрозварювання живих тканин у період до 90 діб.

МАТЕРІАЛИ I МЕТОДИ ВИВчили динаміку кЛінічних та морфологічних змін в ЕМА в умовах хронічного експерименту.

Досліджували зміни в ЕМА через 4; 7; 21; 45 та 90 діб після його створення, 3 погляду виявлення початку та характеристики подальшого перебігу формування тканинних структур у ЕМА порівняно з відомими особливостями загоєння шовного МА.

Комплексне дослідження проведене на 18 свинях породи української великої білої масою 45-75 кг на базі ветеринарного фракультету Національного університету біоресурсів і природокористування України за згодою 
комітету з біоетики, з дотриманням Правил використання експериментальних тварин та Етичних принципів експериментів на тваринах (Київ, 2000), що узгоджуються 3 положеннями Європейської конвенції про захист хребетних тварин, що використовуються для дослідних та інших наукових цілей (Страсбург, 1986).

Після накладання EMA черевну порожнину зашивали, виводили з наркозу та поміщали у вольєр, де одразу дозволяли пити, а з наступного дня - їсти. В плановий період забирали ділянку кишки для фрінального дослідження. Після відбору ділянки кишки для фрінального дослідження тварину в наркозі умертвляли шляхом введення смертельної дози тіопенталу натрію.

Операції виконували після премедикації під ендотрахеальним наркозом. Тваринам у вольєрі вводили премедикацію препаратом "Комбістрес", після седації переносили в операційну та вводили у наркоз. Здійснювали серединну лапаротомію. Під час останньої в рану виводили ділянку тонкої або товстої кишки. Кишку пересікали. Інструмент для створення циркулярного електрозварного з'єднання вводили в просвіт кишки через ентеротомію. Після накладення EMA місце ентеротомії закривали, накладаючи однорядний шов або точкове електрозварне закриття.

Для накладання ЕМА в основній групі використовували джерела електрозварювальних імпульсів ЕК-300М1 та Патонмед ЕКВЗ-300, а також прототипи циркулярних електрозварювальних інструментів.

При відбиранні ЕMА у плановий термін оцінювали його загальний вигляд разом із морфологом та хірургом. Для морфологічного дослідження брали анастомози, які попередньо розтягували рідиною зі зростаючим тиском до 29-33 мм рт. ст. і не виявили втрати герметичності для рідини.

Вказана порогова величина достовірно перевищувала тиск втрати герметичності апаратного скобкового анастомозу, накладеного одноразовим пристроєм для хірургічного використання виробництва Ethicon (США) [13]. Вимірювали тиск за допомогою приєднаного в системи введення рідини електронного манометра DPG8000 M4026/1203 фрірми Omega, США, сертифрікованого за ISO 9001.

Сегмент кишки з накладеним МА занурювали у нейтральний $10 \%$ розчин формаліну та спрямовували на морфологічне дослідження, для проведення якого використовували загальногістологічні методики: забарвлення гематоксиліном та еозином або за Ван-Гізон. Застосовували методи гістохімічного дослідження: компоненти сполучної тканини виявляли за Novelli; фрібрин - зафрарбуванням фоссрорно-вольфрамовим гематоксиліном за Малорі; протеоглікани - ШИК-реакцією із зафрарбуванням ядер гематоксиліном; кислі глікозаміноглікани - зафарбуванням толуїдиновим синім; ліпіди на напівтонких зрізах - за допомогою осмієвої фріксації. Готові препарати досліджували при збільшенні в 100-400 разів.

Досліджували підготовані препарати під світловим (збільшення від 40 до 400 разів) та електронним (збільшення 6000-9600 разів) мікроскопами.

РЕЗУЛЬТАТИ ДОСЛІДЖЕНЬ ТА ЇХ ОБГОВОРЕННЯ Під час первинного оцінювання після створення, неспроможності ЕMA не спостерігали, всі тварини досягли планового терміну виживання після накладання EMA в експерименті, харчувалися і набирали масу без ускладнень.
Через 4 доби ділянка EMA не має ознак ексудативного набряку, є потовщеною та ущільненою, без відкладень фрібрину, зрощень та деформації. За даними гістологічного дослідження, ознак фррагментації, деструкції у ділянці EMA немає. 3 боку слизової оболонки первинно утворений під електродами виразкоподібний дефект сягає підслизового шару, але його краї не мають ознак ексудації, виявлена виражена гіперпластична і проліферативна активність клітин епітелію.

Поміж незмінених тканин в усіх шарах кишки спостерігали окремі залишкові вогнища коагуляційних конгломератів у стані резорбції та організації, без ознак інкапсулювання. Також не виявлено жодних ознак бактеріальної чи спровокованої інфікуванням активності, незважаючи на просякнення тканин на ділянці фрормування грануляційної тканини в зоні зварювання масами фрібрину, нагромадження кислих глікозаміногліканів та протеогліканів.

Натомість виявили активний фрібрилогенез, пронизуючий грануляційну тканину в зоні електрозварного з'єднання колагенових волокон, наявність зрілих волокон, поширення їх з відновленням структурних оболонок стінки кишки. Вздовж волокон у ділянці ЕМА виявили порівняно велику кількість фрункціонуючих новоутворених капілярів, рівномірно в усіх шарах стінки.

Новоутворені колагенові волокна також поширювались у прошарки грануляційної тканини брижі в ділянці EMA.

Через 7 діб від початку експерименту до лінії ЕМА ще зберігається доволі щільне прикріплення прилеглих стінок сечового міхура та петель тонкої кишки, яке вдавалося роз'єднати тупим і гострим способами без руйнації ЕMA. При розтягненні накачуванням рідини до моменту розриву, останній відбувся на віддалі 5 см від лінії ЕМА, за зростання внутрішньопросвітного тиску до 220 мм рт. ст. як і раніше досліджена інтактна кишка, що не містила EMA.

У ділянці ЕМА, порівняно з 4-ю добою, з'явилися ознаки відновлення тканинних структур на тлі триваючої репарації за продуктивним типом. Відзначили виразне витончення лінії електрозварного з'єднання унаслідок візуального ефекту симетричного "зближення" меж незмінених ділянок відрізків кишки, на тлі орієнтації та фрормування жмутків різноспрямованих колагенових волокон, активного кровотоку. Практично завершені процеси резорбції фрібрину та гіперкоагульованих ділянок, окремих конгломератів. При цьому відсутні гранульоми, сторонні включення, мікроорганізми (рис. 1). В слизовому та підслизовому шарі раніше сорормований дефект-виразку частково виповнює сорормована молода сполучна тканина з широкою мережею фрункціонуючих кровоносних судин, вкрита епітелієм на більшості своєї площі. В прилеглих судинах вищого порядку немає ознак запустіння, поодинокі тромби в процесі організації.

Отже, можна стверджувати про фрормування у цей термін не лише наскрізного - через лінію електрозварного з'єднання - міцного каркасного зв'язку, але і про фрункційне відновлення та взаємодію тканин з'єднаних сегментів кишки.

Через 21 добу від створення ЕМА розташований вільно, або легко прикріплений до сечового міхура. Звуження просвіту чи деформації стінки немає, лінія з'єднання тонка - 0,9-1,6 мм, рівна, еластично згинається в усіх напрямках. Слизова оболонка товстої кишки над ЕМА загоїлася. 


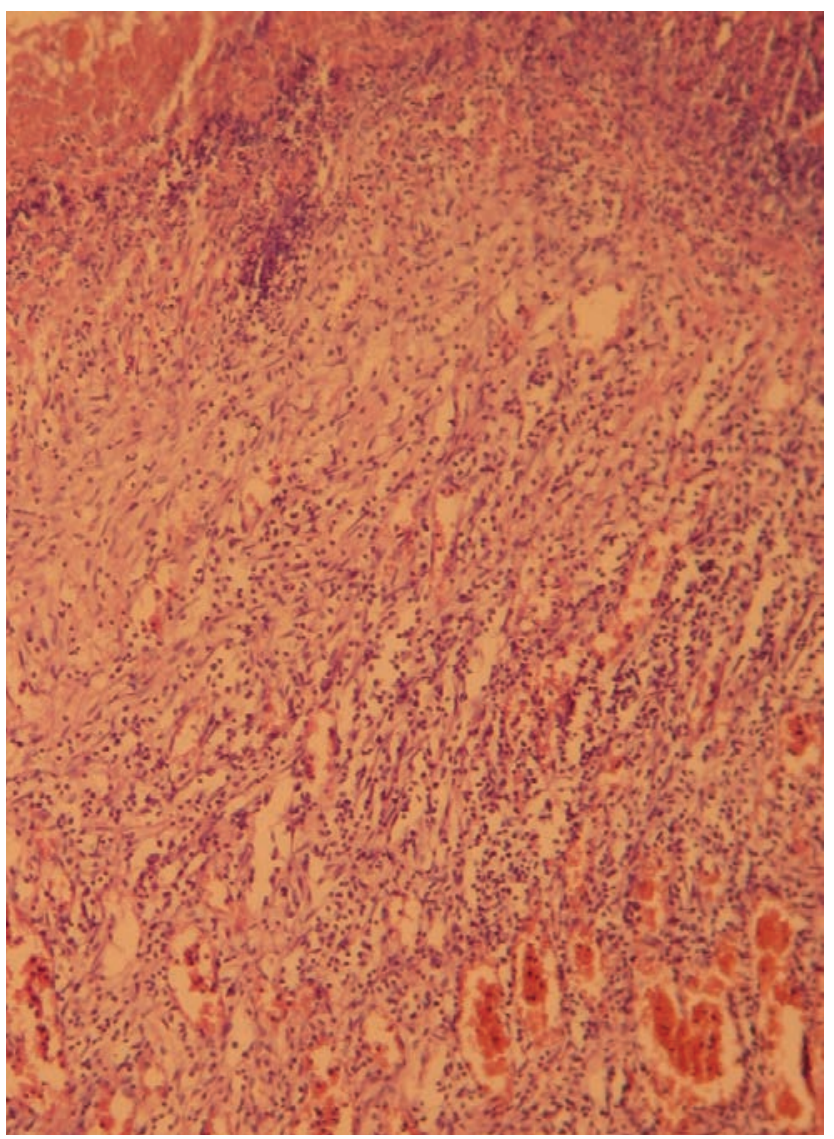

Рис. 1. Тканинна структура зони електрозварного з'єднання $€$ однорідною 3 навколишніми тканинами, містить велику кількість функціонуючих кровоносних судин, на тлі мережива волокон сполучної тканини. Забарвлення гематоксиліном та еозином. ×200.

Тканинна структура ЕMА суцільна й однорідна, не містить ані коагуляційно змінених структур, ані вогнищевих включень: конгломератів, вогнищ фрібриноїдного некрозу чи гіалінозу, специфрічних гранульом, інкапсулятів сторонніх тіл. Залишкові ознаки втручання мінімальні та наявні лише в певних ділянках підслизового шару, по межі лінії з'єднання, де виявлено помірну лімсроцитарну інсрільтрацію. Ознак активного запалення: плазморагії, макрофагальної чи нейтрофрільної інфрільтрації не виявлено.

Над зоною з'єднання практично відновився покрив 3 одношарового плоского епітелію, в якому зазначено наявність поодиноких залоз, у яких відбувається диференціація епітелію. По краях лінії ЕМА - гіперплазія залоз, активне слизоутворення, накопичення протеогліканів у клітинах та в стромі.

При зближенні країв з'єднаних стінок кишки відновлене загальне структурне співпадання однойменних шарів стінки кишки з протилежних відрізків у ділянці ЕМА.

Грануляційна тканина рубця має ніжну структуру, і розташована субепітеліально, а під нею - розростання ніжної волокнистої сполучної тканини.

Власна пластинка слизової оболонки, м'язова пластинка, м'язова оболонка з'єднані проміжками волокнистої сполучної тканини, в яких відмічено орієнтацію за ходом відповідних шарів. Вона мереживом охоплює тканинні структури та окремі м'язові жмутки і проникає на 5 мм углиб стінок з'єднаних країв кишки, переважно вздовж існуючих проміжків і пластинок. На вказаній відстані підслизова основа і стінка кишки набула вигляду інтактної. Водночас, певні волокна мають тангенційну орієнтацію і поширюються в брижі.

У середині рубця, як і в інших ділянках ЕMA, відзначено гіперваскуляризацію. При цьому немає відмежування басейнів кровопостачання з'єднаних відрізків кишки утвореним рубцем. Спостерігаються сорормовані й фрункціонуючі судини різного типу, а наявні в деяких 3 них тромби - реваскуляризовані. Гіперваскуляризація та активний кровоплин відзначені також в брижі (рис. 2).

Під час розгляду в електронному мікроскопі у ділянці електрозварного з'єднання відзначили численні фрібробласти в усіх шарах стінки кишки. Вони активні: мають великий обсяг цитоплазми та містять добре розвинуту ендоплазматичну сітку, що продукує колаген. Колагенові волокна пронизують інтерстицій, оповивають судини. В зоні ЕМА волокна орієнтовані вздовж оболонок та тангенційно. Кровоносні капіляри вистелені функціонально активними ендотеліоцитами.

Через 45 діб лише поодиноке тонке зрощення виявлене в ділянці ЕМА. Ця ділянка кишки - еластична, хоч і дещо потовщена, але мало відрізняється від навколишніх тканин при спробі розтягнення заповненням водою та подальшого згинання петлі кишки. Ззовні лінія з'єднання мало помітна, у вигляді нитки шириною до 1 мм, що не відрізняється за кольором від навколишніх тканин.

Слизова оболонка товстої кишки в цій ділянці також не відрізняється за кольором, містить впритул прилеглі до лінії ЕМА симетричні складки. При морфологічному дослідженні виявлений рубець шириною 1 мм, майже в однаковий рівень 3 навколишньою слизовою оболонкою, вкритий епітелієм. Рубець утворений волокнистою сполучною тканиною, яка поширюється на 2-3 мм обабіч ЕМА в підслизовому шарі, й до 10 мм - в брижі. Легке загальне потовщення стінки відбувається унаслідок посиленої колагенізації мембран, і охоплення колагеновими волокнами як окремих гладком'язових волокон, так і м'язових шарів

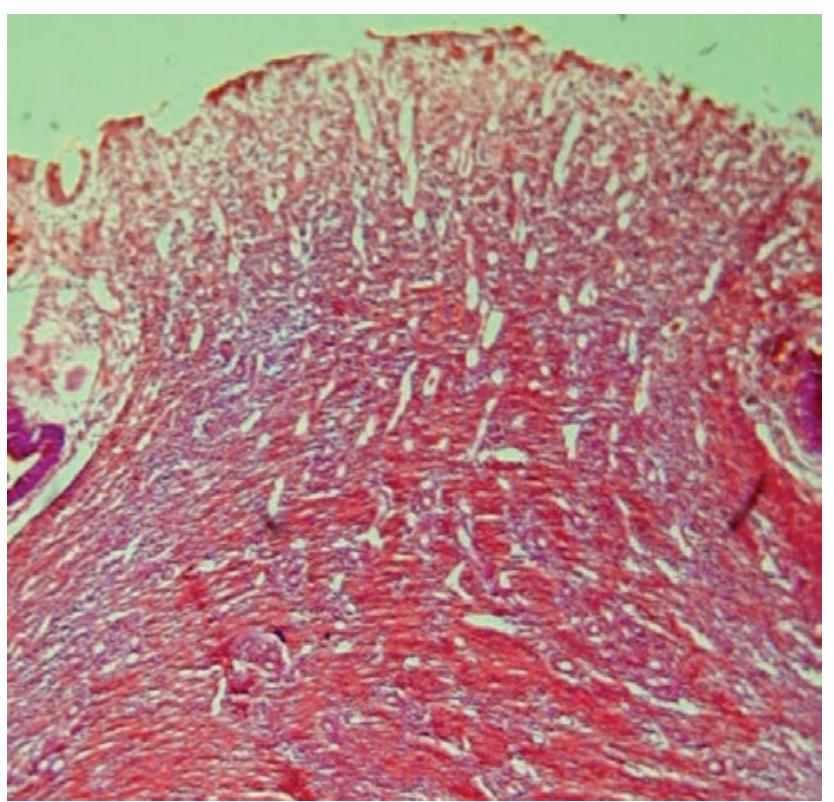

Рис. 2. Відновлене просторове співпадання з'єднаних в ЕМА шарів стінок кишки, відповідна орієнтація тканинних елементів по лінії з'єднання, відновлення епітеліального шару. 
стінки кишки у кожному зі з'єднаних країв, проміжок між якими, відповідно до видимої товщі ЕМА, становить близько 1 мм. Розростання колагенових волокон відзначене також в стінках артерій та вен і вздовж них. Усі судини простежуються наскрізь через лінію ЕМА і містять фрормені елементи крові - ознаку активного кровотоку.

Перевіряючи фрункціональність такого поширення, 3 привідного краю кишки виділили артерію аркади II порядку та в її просвіті закріпили катетер. При введенні 20 мл барвника, розчину метиленового синього в артерію, що постачала кров'ю привідну петлю товстої кишки, спочатку зафарбувалась її стінка суцільним полем забарвлення у всіх шарах, до самої лінії електрозварного з'єднання. Одразу після досягнення лінії ЕMА, крізь внутрішньостінкові судини барвник поширився і на стінку відвідної петлі кишки, почергово на певних ділянках кровопостачання, поширюючись на всю товщу стінки.

Під електронним мікроскопом відзначили триваючу активність фрібробластів, що містять збільшений обсяг гранулярної цитоплазматичної сітки, та оточені жмутками новоутворених колагенових волокон. Інтерстицій містить значну кількість лімсроцитів, що перебувають у контакті з фрібробластами та гладком'язовими волокнами. Цитоплазма останніх містить скупчення міофріламентів та актинміозинових комплексів.

Через 90 діб у ділянці ЕMA відсутні зрощення з петлями тонкої кишки, а лінія ЕМА - еластична та гнучка. Ззовні вона ледь помітна, бо має однакове з кишкою забарвлення, відрізняючись лише контуруванням розташованих обабіч наповнених венул. Слизова оболонка в цій ділянці має дещо змінений малюнок складок, саму лінію не видно.

При дослідженні під мікроскопом товщина стінки кишки на ділянці електрозварного з'єднання є приблизно однаковою з інтактними ділянками. Елементів запальної інсрільтрації в ділянці ЕMA не виявили. Спостережене раніше мережево волокнистої сполучної тканини, яка охоплювала структурні елементи стінки кишки по відповідних шарах від лінії з'єднання обабіч, не має тенденції до злиття у суцільний рубець. Ділянку ЕМА вдається виявити лише за вираженням цього мережива навколо поодиноких гладком'язових волокон на лінії з'єднання, та за місцем збереженого тангенціального переорієнтування всередині мережева сполучної тканини окремих гладком'язових волокон.

Введений в брижову артерію за вищенаведеним способом барвник зафрарбував стінку привідної петлі кишки майже миттєво, а відвідну - швидше та інтенсивніше, ніж у спостереженні через 45 діб (рис. 3).

Спостережена просторова відповідність зіставлення тканин в EMA, мережевний характер його сполучнотканинної структури, наскрізне проростання новоутворених судин знаходяться у відповідності до даних про унікальну відсутність фрази первинних деструктивних змін в структурі EMA, та продуктивного типу загоєння в ньому без ознак фррагментації та бактеріального лізису, які ми отримали раніше [11-13].

Наявність контактуючого через лінію EMA мережева новоутворених капілярів можна вважати провісником початку відновлення тканинних структур в ЕMA.

Вже на 7 добу міцність електрозварного з'єднання перевищувала природну міцність стінки кишки, що свідчить про повне відновлення структурного зв'язку тканин, з'єднаних в EMA країв кишки, а не лише появу грануляційної тканини.

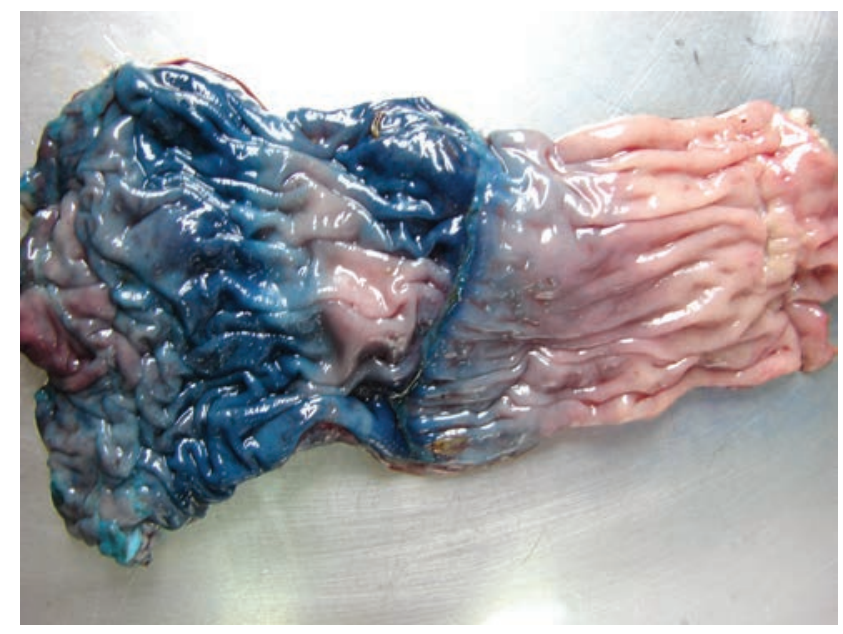

Рис. 3. Відновлення складок слизової оболонки в ділянці ЕМА, інтенсивне та рівномірне проникнення крізь лінію з'єднання метиленового синього, введеного болюсно в привідну артерію.

Морфологічними ознаками якого визначили початок фрормування окремих колагенових волокон в орієнтовані вздовж кишкової стінки жмутки, та наявність френомену зближення країв відрізків кишки в EMA, зі значним зменшенням його ширини. У з'єднаному шовними елементами МА вміст колагену та розривна міцність у цей період лише наближаються до передопераційного рівня для інтактної кишки, але відомостей про перевищення немає $[3,14]$.

Через 21 добу в ділянці ЕМА відбулося відновлення обрисів, а нерідко і повноцінне відновлення сполучнотканинних оболонок поміж шарами відрізків кишки, які зіставлені в просторі через лінію з'єднання, що стає дедалі вужчою що, на нашу думку, є свідченням повного відновлення функції клітин, утворених в товщі ЕМА уздовж відновленої суцільності структурного каркасу. Це підтверджує наявність широкої сітки наскрізних кровоносних капілярів з функціонально активними ендотеліоцитами та активації не лише фрібробластів, але і гладком'язових клітин та залоз епітелію.

У з'єднаному шовними елементами МА про безперервність відновлення оболонок або тканинної структури крізь лінію з'єднання не йдеться, уздовж неї фрормується десормуючий грубий рубець, та/або інкапсуляти сторонніх тіл [6].

За 45 діб ЕМА візуально вирізнявся від навколишньої кишки лише незначним потовщенням, але при цьому зросла еластичність з'єднаних країв кишки, незважаючи на збереження ознак регенераторної активності фрібробластів та міоцитів. Кровобіг через зону з'єднання за потужністю можна назвати регіональним, а не капілярним. Вказане свідчить про переважання процесів диоеренціації в ЕМА.

Через 90 діб посилення частки сполучної тканини в EMA не виявлено, натомість відзначено відновлення суцільності та функційної здатності усіх шарів кишки.

ВИсновкИ 1. Каркасна безперервність оболонок кишечника, що фрормується на ділянці створення електрозварного міжкишкового анастомозу вже на 4-ту добу та фрормування уздовж неї фрункціонуючих капілярів $€$ передумовами багатого наскрізного кровопостачання через зону з'єднання вже через 7 діб, ознак симетричного відновлення в ній уже в цей період тканинної структури стінки кишки, і відсутності стимулів для поширення рубця в просвіт кишечника. 
2. Відсутність у структурі електрозварного з'єднання шовного матеріалу та прониклих мікроорганізмів, інкапсуляції чи фрормування гранульом сторонніх тіл відповідно зменшує та скорочує до 21-ї доби прояви ексудативної та продуктивної стадії запальних реакцій у структурі та поблизу електрозварного міжкишкового анастомозу, виключає формування чинників стимуляції рубцювання ззовні від лінії з'єднання.

3. На 45 добу в електрозварному міжкишковому анастомозі та поблизу нього, на тлі ссрормованого потужного наскрізного кровопостачання переважають процеси відновлення спеціалізованих клітин стінки кишки, що тривають до 90-ї доби без порушення мережевної тканинної структури зони з'єднання, зі збереженням еластичності з'єднання.

Перспективи подальших досліджень Безперервність відновлення тканинної структури кишки у місці електрозварного з'єднання, відсутність рубцевих десормацій мають слугувати основою кращого функційного результату накладення ЕМА порівняно $з$ шовним МА в клінічних умовах.

\section{СПИСОК ЛІТЕРАТУРИ}

1. Донсков А. В. Применение микрохирургического кишечного шва в условиях перитонита при повреждении ободочной кишки / А. В. Донсков, В. К. Есипов, И. И. Каган // Бюллетень ВСНЦ. Иркутск. - 2011. - № 4 (80), ч. 2. - С. 234-236.

2. Механические нарушения под нитью кишечного шва как причина нарушений микроциркуляции в области соустий / В. И. Егоров, И. В. Счастливцев, Р. А. Турусов, А. О. Баранов // Анналы хирургии. - 2002. - № 3. - С. 66-68.

3. Loss of collagen from experimental intestinal anastomoses: early events / T. Hendriks, T. H. Vereecken, W. L. Hesp [et al.] // Exp. Mol. Pathol. - 1985. - Vol. 42 (3). - P. 411-418. - Mode access : https://doi.org/10.1016/0014-4800(85)90090-5

4. Nordentoft T. Sealing of gastrointestinal anastomoses with fibrin glue coated collagen patch / T. Nordentoft // Dan. Med. J. - 2015. - Vol. 62 (5). - P. B5081.

5. Guyton K. L. Prevention of perioperative anastomotic healing complications: anastomotic stricture and anastomotic leak / K. L. Guyton, N. H. Hyman, J. C. Alverdy // Advances in Surgery. - 2016. Vol. 50 (1). - P. 129-141. doi:10.1016/j.yasu.2016.03.011

6. Intestinal anastomotic injury alters spatially defined microbiome composition and function / B. D. Shogan, D. P. Smith, S. Christley [et al.] // Microbiome. - 2014. - Vol. 2. - P. 35. - Mode access: http:// doi.org/10.1186/2049-2618-2-35

7. Рентгенорадионуклидный метод диагностики ранних осложнений после операции на толстой кишке / [B. Н. Нуреев, В. М. Леонтьев, А. М. Воротников и др.] // Актуальные вопросы специализированной медицинской помощи. - М. : Военное издательство, 1988. - С. 217-219.
8. Bowel dysfunction after low anterior resection with and without neoadjuvant therapy for rectal cancer: a population-based crosssectional study / S. Bregendahl, K. J. Emmertsen, J. Lous, S. Laurberg // Colorectal Dis. - 2013. - Vol. 15 (9). - P. 1130-1139. doi: 10.1111/codi.12244

9. Compression versus hand-sewn and stapled anastomosis in colorectal surgery: a systematic review and meta-analysis of randomized controlled trials / A. A. Slesser, G. Pellino, O. Shariq [et al.] // Tech. Coloproctol. - 2016. - Vol. 20 (10). - P. 667-676. doi: 10.1007/s10151-016-1521-8

10. Davis B. Complications of colorectal anastomoses: leaks, strictures, and bleeding / B. Davis, D. E. Rivadeneira // Surg. Clin. North Am. - 2013. - Vol. 93 (1). - P. 61-87. doi: 10.1016/j. suc.2012.09.014

11. Антибактерійна стійкість електрозварного з'єднання живих тканин / С. С. Подпрятов, С. Г. Гичка, І.М.Слободянюк // Клінічна хірургія. - 2017. - Т. 9. - С. 55-57. doi.org/10.26779/25221396.2017.09.55

12. Особливості перебігу пролісрерації у міжкишкових анастомозах, створених з застосуванням технології електрозварювання живих тканин / С. С. Подпрятов, С. Є. Подпрятов, В. Г. Гетьман [та ін.] // Хірургія України. - 2018. - № 2. - С. 60-64. doi.org/10.30978/SU2018260

13. Тканесохраняющая высокочастотная электросварочная хирургия: атлас ; за ред. Б. Є. Патона, О. М. Іванової. - К. : Наукова думка, 2009. -- $193 \mathrm{c}$.

14. Colorectal anastomotic healing: why the biological processes that lead to anastomotic leakage should be revealed prior to conducting intervention studies / J. W. A. M. Bosmans, A. C. H. M. Jongen, N. D. Bouvy, J. P. M. Derikx // BMC Gastroenterology. - 2015. Vol. 15. - P. 180. doi:10.1186/s12876-015-0410-3

Отримано 24.10.18

Електронна адреса для листування: sspodpr@gmail.com

(C). S. Podpriatov 1,2,4, S. E. Podpryatov ${ }^{1,2,3}$, S. G. Gichka'2, V. G. Hetman ${ }^{4}$, A. V. Makarov ${ }^{4}$, G. S. Marinsky ${ }^{3}$, O. F. Petrenko ${ }^{5}$, O. V. Chernets ${ }^{3}$, V. A. Tkachenko ${ }^{3}$, D. V. Tarnavsky ${ }^{5}$ Kyiv City Centre of Bonding/Welding Surgery and New Surgical Technologies ${ }^{1}$ Kyiv City Clinical Hospital No. $1^{2}$ Ye. Paton Electric Welding Institute of National Academy of Sciences ${ }^{3}$ P. Shupyk National Medical Academy of Postgraduate Education ${ }^{4}$ National University of Bioresources and Nature Management of Ukraine ${ }^{5}$

\section{TISSUE STRUCTURES REPARATION FEATURES IN THE GUT ANASTOMOSES DURING 90 DAYS PERIOD AFTER CREATING BY LIVE TISSUES WELDING TECHNOLOGY}

Summary. The bacterial inflammation obligatory arises after ischemic necrosis under the sutures in the intestinal wall inside uncomplicated intestinal anastomosis. It determines the healing type causes cicatricial replacement of intestinal tissue, additionally supported by suture material encapsulation and rejection process. 
The aim of the study - to investigate the tissue structures reparation features in the intestinal anastomosis, created by using the Live Tissues Electric Welding Technology, during the period of tissue reparation and scar origin.

Materials and Methods. Changes in intestinal anastomoses were studied after 4, 7, 21, 45 and 90 days after its creation from the positions of gut wall tissues structure reparation. A circular electrowelded small intestinal anastomosis was applied in 18 pigs in a chronic experiment. The electric welding devices EK-300M1 and Patonmed-300 were used, as well as prototypes of surgical instrument for circular intestinal anastomoses creating. The hematoxylin-eosin and Van Gieson histopathologic techniques were used.

Results and Discussion. In 7 days, the strength of the welded anastomosis exceeds $220 \mathrm{~mm} \mathrm{Hg}$, because outstanding tissue was ruptured. The signs of tissue structure reparation appeared: the welded zone thinning with symmetrical approach of the visually unaltered areas of anastomosed intestines, compared to 4 days. Also, differently directed at 4 day collagen fibers are becoming orientation and bundles formation. The young connective tissue comprised a wide network of newly formed functioning blood arteriols. In 21 day none inflammatory sign was present. Fibrous connective tissue networks the separate muscle bundles, and penetrates $5 \mathrm{~mm}$ into the connected gut edges. Various ranges of vessels yet formed and functions. In 45 days tissue thickening due to membranes collagenization as well as muscle layers, arteries and veins coverage by collagen fibers are noted. The vessels pass right through the welding anastomose line, and are quickly coloured. In 90 days, the fibrous network has not tend to merge into a continuous scar, and the anastomose line can be determined only by network expression around individual smooth muscle fibers, and by point of fibers tangential orientation change. The mucosal folds are restored up to line.

Conclusions. The frame continuity of the anastomosed intestinal walls, which is restored at the electric welding site is a prerequisite for the rich capillary blood supply and symmetrical restoration of the tissue structure of the intestinal wall after 7 days. The foreign bodies and microorganisms absence in the welded intestinal anastomosis structure leads to inflammation components disappearance during 21 days, which also provides the scar structure formation in delicate pathway, avoiding cicatrix tissue replacement.

Key words: electric welding; tissue; anastomosis; colon; intestine; reparation; structure; vessels; scar; healing.

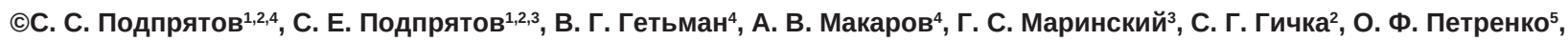
А. В. Чернец ${ }^{3}$, В. А. Ткаченко ${ }^{3}$, Д. В. Тарнавский

Киевский городской центр электросварочной хирургии и новых хирургических технологий Киевская городская клиническая больница № $1^{2}$ Институт электросварки имени Е. О. Патона НАН Украины ${ }^{3}$ Национальная медицинская академия последипломного образования имени П. Л. Шупика ${ }^{4}$ Национальный университет биоресурсов и природопользования Украины $1^{5}$

\section{ОСОБЕННОСТИ ВОССТАНОВЛЕНИЯ ТКАНЕВЫХ СТРУКТУР В ПЕРИОД ДО 90 СУТОК В МЕЖКИШЕЧНОМ АНАСТОМОЗЕ,} СОЗДАННОМ С ИСПОЛЬЗОВАНИЕМ ТЕХНОЛОГИИ ЭЛЕКТРОСВАРКИ ЖИВЫХ ТКАНЕЙ

Резюме. Наличие гнойно-некротического воспаления под швами в межкишечном анастомозе определяет заживление грубым рубцом, который замещает тканевую структуру на фоне инкапсуляции и отторжения шовного материала.

Цель исследования - изучить особенности восстановления тканевых структур в области межкишечного анастомоза, созданного с применением технологии электросварки живых тканей в период репарации и формирования рубца.

Материалы и методы. Исследовали изменения в межкишечном анастомозе через 4; 7; 21; 45 и 90 суток после его создания с точки зрения восстановления структуры тканей и стенки кишки. Циркулярный электросварной тонко-тонкокишечный анастомоз наложили у 18 свиней в хроническом эксперименте. Использовали электросварочные аппараты ЕК-300М1 и Патонмед ЭКВ3-300, а также прототипы циркулярных электросварочных инструментов. Базовое окрашивание препаратов анастомоза проводили за гематоксилином и еозином или по Ван-Гизон.

Результаты исследований и их обсуждение. Через 7 суток прочность электросварочного анастомоза на разрыв превысила 220 мм рт. ст. Появились признаки восстановления тканевых структур: симметричное сближения границ визуально неизмененных участков кишки, по сравнению с 4 сутками, на фоне ориентации и фрормирования пучков разнонаправленных коллагеновых волокон. Сформирована молодая соединительная ткань с сетью артериол. Через 21 сутки признаков воспаления не было. Волокнистая соединительная ткань кружевами охватывает тканевые структуры и проникает на 5 мм вглубь симметрично соединенных краев кишки. Функционируют сосуды разного типа. Через 45 суток имеется коллагенизация вдоль всех мембран и оболочек. Сосуды соединенных участков окрашиваются сквозь линию анастомоза. Через 90 суток тенденции к слиянию в сплошной рубец нет, складки слизистой восстановлены, а линия соединения едва определяется по изменению ориентации волокон.

Выводы. Каркасная непрерывность оболочек кишечника, которая восстанавливается в месте создания электросварного анастомоза, является предпосылкой богатого сквозного кровоснабжения и симметричного восстановления тканевой структуры стенки кишки уже через 7 суток. Отсутствие посторонних тел и микроорганизмов в структуре электросварного анастомоза приводит к исчезновению воспаления через 21 сутки, что также является составляющим фрормирования кружевной нежной, а не замещающей структуры соединенительной ткани в нем.

Ключевые слова: электросварка; ткань; анастомоз; кишка; восстановление; структура; сосуды; рубец; заживление. 